\title{
HBA2 Gene
}

National Cancer Institute

\section{Source}

National Cancer Institute. HBA2 Gene. NCI Thesaurus. Code C75432.

This gene plays a role in oxygen transport. 